\title{
Pengaruh Terpaan Akun Instagram @bekasifood Terhadap Preferensi dalam Memilih Kuliner di Bekasi
}

\author{
Muhamad Andi Wiryawan', Widyo Nugroho \\ ${ }^{1,2}$ Fakultas Ilmu Komunikasi, Universitas Gunadarma \\ Email: andiwiryawan73@gmail.com
}

\begin{abstract}
Instagram account @ bekasifood is an account that often shares various culinary informations. This information can be used as a basis and reference for the tendency of the community or followers of the account in choosing the type of culinary. This study aims to determine the effect of exposure to the Instagram account @bekasifood on preferences in choosing culinary in Bekasi. The research method used is a quantitative method with the main theory of Uses and Gratification. Determination of the sample size in this study uses the Taro Yamane formula. Based on the result of hypothesis testing, namely the T test and F test, the result shows that preference in choosing culinary in Bekasi can be influenced by exposure to the Instagram account @bekasifood. Aimed at the simple linear regression test and t test that motives affect preference in choosing culinary in Bekasi. The hypothesis which states that "there is a significant effect of exposure to the @bekasifood Instagram account on preferences in choosing culinary in Bekasi for followers is accepted. In this study, it can be seen that the value of the coefficient of determination R Square is 0.733. These result explains the ability of the account exposure variable $(X)$ to influence the preference variable in choosing culinary $(Y)$ followers of the @bekasifood Instagram account, which is 73.3\%, while the rest is explained by other factors not found in this study.
\end{abstract}

Keywords: instagram exposure; uses and gratification; culinary preference

\begin{abstract}
Abstrak: Akun Instagram @ bekasifood adalah salah satu akun yang sering membagikan berbagai informasi seputar kuliner. Informasi-informasi tersebut bisa menjadi dasar dan referensi pada kecenderungan masyarakat atau follower akun tersebut dalam memilih jenis kuliner. Penelitian ini bertujuan untuk mengetahui pengaruh terpaan akun Instagram @bekasifood terhadap preferensi dalam memilih kuliner di Bekasi. Metode penelitian yang digunakan adalah metode kuantitatif dengan teori utama Uses and Gratification. Penentuan ukuran sampel dalam penelitian ini menggunakan rumus Taro Yamane. Berdasarkan hasil uji hipotesis, yaitu uji $\mathrm{T}$ dan uji $\mathrm{F}$, hasil penelitian menunjukkan bahwa preferensi dalam memilih kuliner di Bekasi dapat dipengaruhi oleh terpaan akun Instagram @ bekasifood. Ditujukan pada uji regresi linear sederhana serta uji t bahwa motif berpengaruh terhadap preferensi dalam memilih kuliner di Bekasi. Hipotesis yang menyatakan bahwa "terdapat pengaruh yang signifikan terpaan akun Instagram @ bekasifood terhadap preferensi dalam memilih kuliner di Bekasi bagi followers diterima. Penelitian ini dapat diketahui besar nilai koefisien determinasi R Square adalah 0,733. Hasil ini menjelaskan kemampuan variabel terpaan akun (X) dapat mempengaruhi variabel preferensi dalam memilih kuliner (Y) followers akun instagram @ bekasifood, yaitu sebesar 73,3\%, sedangkan sisanya dijelaskan oleh faktor lain yang tidak terdapat pada penelitian ini.
\end{abstract}

Kata kunci: terpaan instagram; uses and gratification; preferensi memilih kuliner

\section{Pendahuluan}

Komunikasi menjadi aspek sangat penting dalam kehidupan masyarakat. Dalam aktivitas komunikasi seorang individu dapat memberikan atau bertukar informasi yang diperlukan (Meilinda, 2018; Hidayat, 2017). Komunikasi dapat dipahami melalui cara menjawab konsep pertanyaan yang diajukan Lasswell, yaitu Who Says What In Which Channel To Whom With What Effect (Siapa mengatakan apa, melalui saluran apa, kepada siapa dan berefek apa) 
(Khumaedi \& Diniyati, 2020; Perdana, 2021). Konsep ini bertujuan untuk mempengaruhi khalayak sasaran dalam melancarkan proses komunikasi melalui pesan yang disampaikan, sehingga diharapkan melahirkan beberapa efek tertentu terutama dalam komunikasi massa (Ruslan, 2016).

Dalam beberapa tahun belakangan, aktivitas komunikasi manusia tidak hanya dilakukan menggunakan media massa terutama konvensional, melainkan sudah merambah ke dalam bentuk media sosial. Perubahan pola perilaku komunikasi ini dipengaruhi oleh perkembangan pesat teknologi komunikasi dan informasi yang terutama belakangan didorong oleh penemuan internet. Internet memungkinkan manusia saling terhubung satu sama lain di seluruh dunia sehingga memudahkan mereka dalam mengakses segala macam bentuk informasi (Tobing, 2019; Herlambang, 2014). Tidak hanya itu, keberadaan internet juga semakin mempermudah proses terjadinya komunikasi antar manusia terutama di Indonesia (Lestari, 2018; Juwita et al., 2015).

Indonesia merupakan salah satu negara dengan jumlah pengguna internet terbanyak di dunia. Jumlah pengguna internet Indonesia terus bertambah dari tahun ke tahun. Menurut survei Asosiasi Penyelenggara Jasa Internet Indonesia (APJII) hingga kuartal II tahun 2020, jumlah pengguna internet Indonesia ada sekitar 196,7 juta orang atau 73,7 persen dari total populasi masyarakat Indonesia 266,9 juta berdasarkan data BPS. Angka tersebut mengalami kenaikan sebesar 8,9 persen atau setara 25,5 juta pengguna dari periode yang sama pada tahun lalu (APJII, 2020).

Peningkatan jumlah pengguna internet mengindikasikan masyarakat yang semakin membutuhkan informasi. Masyarakat menggunakan berbagai cara untuk mendapatkan informasi, mulai memperolehnya dari melalui media konvensional seperti televisi, radio, media cetak hingga media sosial. Pada perkembangan yang paling belakangan, baik secara individu maupun berkelompok setiap porang merasa butuh menggunakan media sosial sebagai cara paling mutakhir untuk memperoleh informasi yang mereka butuhkan. Ada berbagai macam media sosial yang digunakan masyarakat untuk mengakses informasi, seperti Facebook dan Instagram. Walaupun sama-sama termasuk ke dalam jenis media sosial, namun keduanya memiliki kerakteristik yang berbeda. Facebook terkenal sebagai media sosial yang digunakan untuk mencari teman atau komunitas hobi, sedangkan Instagram hanya fokus pada pengambilan gambar atau video, lalu mengeditnya dan diunggah. Selain Facebook dan Instagram, masih banyak media sosial yang lain, seperti Twitter, Lina dan lain sebagainya dengan kegunaan yang berbeda-beda. Namun secara garis besar fungsi dari media sosial adalah untuk mempermudah individu dalam berinteraksi, mencari dan menyampaikan informasi ke publik, dan juga menghubungkan diri ke seluruh dunia (Sukrillah et al., 2018; Purbohastuti, 2017; Cahyono, 2016).

Media sosial adalah alat yang digunakan oleh individu dalam proses sosial. Media sosial bisa digunakan sebagai alat sosial dalam berbagai bidang, mulai dari bidang politik, ekonomi, periklanan dan lain sebagainya (Mulawarman \& Nurfitri, 2017). Namun dalam arti yang spesifik bisa didefinisikan bahwa media sosial adalah alat yang digunakan dalam proses sosial di mana alat tersebut bisa menghubungkan individu ke seluruh dunia selama masih terhubung ke dalam jaringan internet. Media sosial didefinisikan sebagai layanan berbasis Web yang memungkinkan individu mampu membangun profil publik, mengatur daftar pengguna lain seperti dengan siapa mereka berbagi koneksi, melihat dan menunjukan daftar koneksi yang dimiliki dan yang dibuat oleh orang lain. Itulah sebab dikatakan media sosial memiliki manfaat yang menakjubkan (Lori, 2013). 
Media sosial yang populer saat ini adalah Instagram. Instagram diluncurkan pada 6 Oktober 2010 dengan perancang awal Kevin Systrom dan Mike Krieger. Aplikasi Instagram digemari semua kalangan masyarakat, mulai dari remaja hingga orang tua yang ingin memantau kegiatan anaknya di media sosial. Penggunaan aplikasi Instagram pun cukup mudah, dimulai dari membuka aplikasi Google Play atau App Store, mengunduh aplikasi tersebut lalu mendaftarkan diri menjadi pengguna.

Penggunaan Instagram atau media tertentu pada umumkan dikaitkan dengan tingkat kepuasan yang diperoleh oleh penggunanya, baik dalam menggunakan media tersebut maupun dalam mengkonsumsi informasi-informasi yang ada di dalamnya. Dalam pandangan teori Uses and Gratification masyarakat atau khalayak memiliki pilihan alternatif untuk memuaskan kebutuhannya, yang berarti khalayak memiliki peran aktif dalam memilih dan menggunakan media tertentu (Effendy, 2017). Katz dan Blumer mengemukakan bahwa teori ini meneliti tentang asal mula kebutuhan secara psikologis dan sosial yang menimbulkan harapan-harapan tertentu dari media. Pada tahap selanjutnya hal ini membawa pada pola terpaan media yang berlainan atau keterlibatan pada kegiatan lain dan menimbulkan pemenuhan kebutuhan dan akibat-akibat lain (Nurudin, 2017). Teori ini didasarkan pada lima asumsi dasar, yaitu bahwa (1) Khalayak aktif dan penggunaan medianya berorientasi pada tujuan, (2) Inisiatif dalam menghubungkan kebutuhan akan kepuasan terhadap pilihan media tertentu bergantung pada anggota khalayak, (3) Media berkompetisi dengan sumber kebutuhan lain, (4) Orang memiliki kesadaran diri yang cukup akan penggunaan media mereka, minat, motif, sehingga dapat memberikan gambaran yang akurat pada peneliti, dan (5) Keputusan pada nilai mengenai bagaimana khalayak menghubungkan kebutuhannya dengan media atau isi tertentu seharusnya ditunda (Baran \& Davis, 2018).

Teori Uses and Gratification memandang khalayak atau pengguna mendasarkan penggunaan media massa pada motif-motif tertentu. Media dianggap berusaha memenuhi motif tersebut. Jika motif terpenuhi maka kebutuhan khalayak akan terpenuhi. Sebagai ujung dari pandangan ini, media yang memenuhi kebutuhan khalayak disebut media efektif (Kriyantono, 2009). Dengan demikian, penggunaan media sosial, dalam hal ini Instagram, juga didasarkan pada motif-motif tertentu, di mana motif-motif tersebut mengantarkan setiap pengguna pada pemenuhan kepuasan akan kebutuhan.

Para pengguna pada umumnya menganggap bahwa fungsi dari Instagram hanya sebatas untuk interaksi sosial, berbagi foto dan video, serta untuk meningkatkan popularitas dengan banyaknya followers. Hal itu benar, namun fungsi Instagram secara luas lebih dari itu, yaitu untuk membangun interaksi antar pengguna, rekomendasi tempat hiburan, mencari dan berbagi informasi atau pengetahuan, serta sebagai saran untuk pemasaran melalui berbagai fitur seperti Direct Message dan juga komentar. Instagram menyediakan akun bisnis sehingga dapat digunakan oleh para pelaku bisnis apa pun termasuk kuliner sebagai sarana promosi dan semacamnya. Media ini bisa dikatakan cukup efektif digunakan menimbang masyarakat dewasa ini yang lebih banyak mengkonsumsi media sosial daripada media massa konvensional. Jika dilihat dari pengguna media sosial yang semakin banyak dari waktu ke waktu, maka tidak mengherankan jika banyak pelaku bisnis menggunakan media ini, terutama Instagram, sebagai salah satu media penting untuk menyebarkan informasi produk, baik barang maupun jasa. Media sosial Instagram dijadikan sebagai salah satu media dalam komunikasi pemasaran. Hal ini berkaitan dengan karena dewasa ini semakin banyak masyarakat apalagi generasi milenial yang 
menggunakan media sosial Instagram baik dalam berinteraksi sosial maupun dalam mencari informasi-informasi yang diinginkan, termasuk salah satunya informasi tentang kuliner.

Akun Instagram @ bekasifood adalah salah satu akun yang sering membagikan berbagai informasi seputar bisnis terutama kuliner yang dibuat pada tanggal 26 Oktober 2015 oleh Mario Adi Prasetyo. Terhitung sejak dibuat akun ini telah memiliki pengikut (followers) sebanyak 72 ribu atau tepatnya 72.213 ribu pengguna (per 12 Juni 2021). Jumlah ini terbilang lebih unggul dibandingkan dengan akun sejenisnya. Informasi-informasi yang disampaikan akun @ bekasifood selalu terbaru dan petugas administrasi akun ini sangat aktif memberikan respon pada pengikutnya. Setiap hari akun @bekasifood mengunggah foto maupun video yang berhubungan dengan kuliner yang sedang dicari oleh masyarakat di daerah kota dan kabupaten Bekasi. Terhitung per 12 Juni 2021 akun @bekasifood telah memiliki 3 (tiga) ribu unggahan informasi mengenai kuliner.

Sebenarnya, ada beberapa akun Instagram yang juga memberikan berbagai informasi mengenai kuliner atau makanan. Walaupun demikian dari sekian jumlah akun Instagram yang dimaksud, akun @bekasifood memiliki lebih banyak pengikut dibandingkan akun-akun Instagram lain yang sama-sama memberikan informasi mengenai kuliner. Selain itu jumlah unggahan akun @bekasifood juga lebih banyak dibandingkan beberapa akun Instagram sejenis. Akun@bekasifood mengunggah informasi-informasi kuliner setiap 2 (dua) hari sekali bahkan tidak jarang juga setiap hari.

Keberadaan akun Instagram @bekasifood dapat membantu masyarakat terutama mahasiswa dalam mencari informasi kuliner yang diinginkan. Keberadaan akun@bekasifood selain menampilkan foto ataupun video yang menarik, juga memberikan informasi-informasi tambahan yang dibutuhkan oleh mahasiswa seperti alamat, suasana, jam operasional hingga harga yang dikeluarkan apabila berkunjung ke tempat kuliner tersebut. Kenyataannya, banyak mahasiswa di Bekasi yang membutuhkan preferensi kuliner terpercaya dan sesuai dengan ekspektasi mereka.

\section{Metode Penelitian}

Metode yang digunakan dalam penelitian ini adalah kuantitatif dengan pengumpulan data menggunakan kuesioner sebagai data primer dan studi kepustakaan sebagai data sekunder. Populasi dalam penelitian ini adalah followers akun Instagram @bekasifood yang memiliki 72.213 ribu pengguna (per 12 Juni 2021). Peneltian ini menggunakan teknik purposive sampling sebagai penentu sampel penelitian. Penentuan jumlah sampel menggunakan rumus Taro Yamane, karena digunakan untuk populasi yang besar yang diperoleh dari pendugaan proporsi populasi (Kriyantono, 2016). Hasil yang diperoleh adalah sebanyak 400 responden untuk dijadikan sampel penelitian dengan menggunakan kuesioner sebagai alat pengumpulan data.

Media yang diteliti adalah media sosial Instagram dengan akun @ bekasifood. Indikator variable X yakni terpaan informasi yang menurut Ardianto (2004) meliputi frekuensi, durasi, dan perhatian. Selanjutnya indikator variable Y, yakni preferensi, yang merupakan kesukaan atau kecenderungan hati kepada sesuatu, meliputi keinginan dan pengalaman.

\section{Hasil dan Pembahasan}

Berdasarkan jenis kelamin dari 406 responden yang diperoleh, mayoritas responden berjenis kelamin perempuan, yaitu sebanyak 210 orang dengan persentase $51,8 \%$, sisanya adalah 
responden berjenis kelamin laki-laki yaitu sebanyak 196 orang dengan persentase 48,2\%. Dari segi usia mayoritas responden berusia 23-28 tahun yaitu sebanyak 297 orang dengan persentase $73,2 \%$. Responden dengan kelompok usia 17-22 tahun yaitu sebanyak 72 orang dengan persentase $17,9 \%$. Responden dengan kelompok usia $>29$ tahun yaitu sebanyak 37 orang dengan persentase $8,9 \%$. Selanjutnya berdasarkan durasi mengikuti akun Instagram @bekasifood mayoritas sudah mengikuti lebih dari 12 bulan yaitu sebanyak 265 orang dengan persentase $65,2 \%$. Responden dengan durasi mengikuti 6-12 bulan sebanyak 75 orang dengan persentase $18,5 \%$ dan responden dengan durasi mengikuti 1-3 Bulan sebanyak 66 responden 16,3\%.

\section{Uji Validitas}

Uji validitas menggunakan SPSS V.23, uji validitas ini dilakukan dengan signifikansi 5\% atau tingkat kepercayaan $95 \%$. Nilai $r$ tabel dengan $\mathrm{N}=120$ pada signifikansi $5 \%$ pada distribusi nilai tabel statistik, maka diperoleh nilai $r$ tabel sebesar 0,179. dimana suatu butir pernyataan dikatakan valid jika nilai $r$ hitung $>$ dari $r$ tabel. Dari pengujian validitas dengan menggunakan SPSS V.23 maka didapatkan hasil bahwa butir pernyataan variabel X dan Y dinyatakan valid. Hal ini dikarenakan $r$ hitung > dari $r$ tabel, dengan tingkat signifikansi 5\% yang melalui uji dua arah dengan $r$ tabel sebesar 0,400 .

\section{Uji Reliabilitas}

Uji reliabilitas dilakukan dengan menggunakan aplikasi SPSS V.23, dengan diukur berdasarkan Cronbach Alpha. Dalam uji reliabilitas ini Apabila hasil Cronbach Alpha > dari 0,6 maka kuesioner tersebut reliabel. Dari hasil pengujian reliabilitas pada variabel $\mathrm{X}$ terpaan akun dari 11 item pernyataan, nilai Cronbach Alpha yang didapat adalah 0,704 maka nilai tersebut > dari 0,6, dan variabel Y preferensi dari 5 item pernyataan pada variable Y, nilai Cronbach Alpha yang di dapat adalah 0,503 maka nilai tersebut > dari 0,6. Maka dapat ditarik kesimpulan bahwa pernyataan atau alat ukur kuesioner dalam penelitian ini reliabel.

\section{Uji Asumsi Klasik}

\section{Uji Normalitas}

Menurut Widodo (2017), uji normalitas bertujuan untuk mengetahui distribusi residual. Model yang baik mempunyai residual berdistribusi normal. Diketahui bahwa nilai signifikansi dalam penelitian ini sebesar 0,151>0,05 sehingga dapat disimpulkan bahwa data yang di uji berdistribusi normal.

\section{Uji Linieritas}

Uji linearitas bertujuan untuk mengetahui apakah dua variabel mempunyai hubungan yang linear atau tidak secara signifikan. Uji ini biasanya digunakan sebagai syarat dalam analisis korelasi atau regresi linear. Disimpulkan bahwa nilai sig. Deviation from linearity lebih besar dari $>0,1$, yaitu 0,371 >0,1 maka terdapat suatu hubungan yang linear antara variabel bebas dengan variabel terikat. 
Tabel 1. Uji Linieritas

ANOVA Table

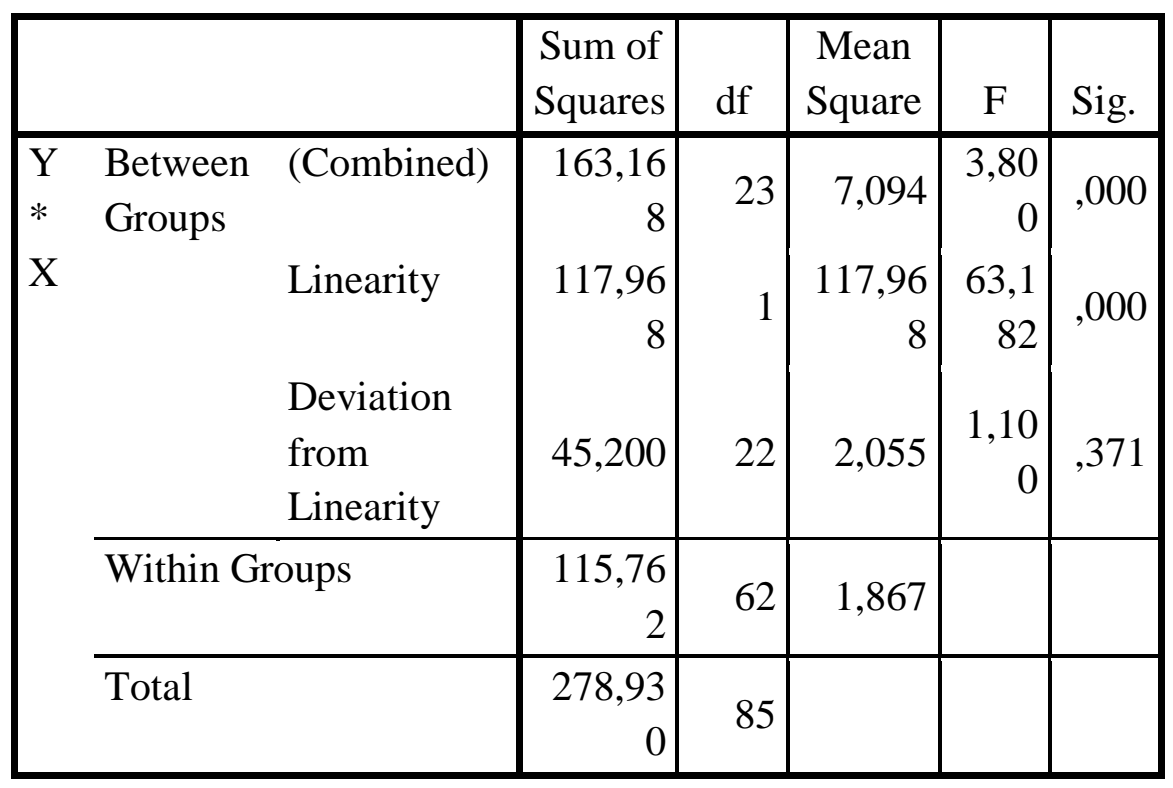

\section{Uji Heteroskedastisitas}

Uji heteroskedastisitas dilakukan untuk menguji terjadinya perbedaan variance residual suatu periode pengamatan ke periode pengamatan lainnya. Jika varians dari residual satu pengamatan ke pengamatan lain tetap, maka disebut homokedastisitas dan jika berbeda disebut heteroskedastisitas (Widodo, 2017). Jika nilai signifikansi (Sig) antara variabel independent dengan absolut residual lebih besar dari 0,05 maka tidak terjadi masalah heteroskedastisitas. Dari hasil yang didapat, maka dapat disimpulkan bahwa nilai signifikansi variabel $\mathrm{X}=0,073>$ dari 0,05 artinya tidak ada gejala heteroskedastisitas karena nilai Sig. lebih besar dari 0,05.

Tabel 2. Uji Heteroskedastisitas

Coefficients $^{\mathbf{a}}$

\begin{tabular}{|c|c|c|c|c|c|}
\hline \multirow[b]{2}{*}{ Model } & \multicolumn{2}{|c|}{$\begin{array}{l}\text { Unstandardized } \\
\text { Coefficients }\end{array}$} & \multirow{2}{*}{$\begin{array}{c}\begin{array}{c}\text { Standardized } \\
\text { Coefficients }\end{array} \\
\text { Beta }\end{array}$} & \multirow[b]{2}{*}{$\mathrm{t}$} & \multirow[b]{2}{*}{ Sig. } \\
\hline & B & Std. Error & & & \\
\hline (Constant) & 1,989 &, 533 & & 3,731 & ,000 \\
\hline $\begin{array}{l}\text { Terpaan } \\
\text { Akun }\end{array}$ &,- 026 &, 014 &,- 089 & $-1,799$ & ,073 \\
\hline
\end{tabular}

a. Dependent Variable: RES2

\section{Uji Analisis regresi Sederhana}

Uji regresi linier sederhana adalah suatu model persamaan yang menggambarkan hubungan satu variabel bebas atau predictor (X) dengan satu variabel terikat atau response (Y) yang biasanya digambarkan dengan garis lurus. Tujuan dari regresi linear sederhana adalah digunakan untuk menguji pengaruh satu variabel bebas terhadap variabel terikat. Syarat untuk uji regresi linear sederhana, yaitu: valid dan reliabel, normal dan linear. Diperoleh koefisien untuk variabel Terpaan Akun (X) sebesar 0,211 dan konstanta sebesar 8,973. 
Tabel 3. Analisis regresi Sederhana

Coefficients $^{\mathbf{a}}$

\begin{tabular}{|c|c|c|c|c|c|c|}
\hline \multirow{2}{*}{\multicolumn{2}{|c|}{ Model }} & \multicolumn{2}{|c|}{$\begin{array}{c}\text { Unstandardized } \\
\text { Coefficients }\end{array}$} & \multirow{2}{*}{$\begin{array}{c}\text { Standardized } \\
\text { Coefficients }\end{array}$} & \multirow[b]{2}{*}{$\mathrm{t}$} & \multirow[b]{2}{*}{ Sig. } \\
\hline & & $\mathrm{B}$ & Std. Error & & & \\
\hline \multirow[t]{2}{*}{1} & (Constant) & 8,973 & ,913 & & 9,828 & ,000 \\
\hline & $\begin{array}{l}\text { Terpaan } \\
\text { Akun }\end{array}$ &, 211 & ,024 & ,395 & 8,630 & ,000 \\
\hline
\end{tabular}

a. Dependent Variable: Preferensi

\section{Uji T}

Tujuan uji $\mathrm{T}$ adalah untuk mengetahui ada atau tidaknya pengaruh parsial (sendiri) yang diberikan variabel bebas (X) terhadap variabel terikat (Y). Adapaun dasar pengambilan keputusan sebagai berikut:

a. Jika nilai sig $<0,05$, atau $t$ hitung $>\mathrm{t}$ tabel maka terdapat pengaruh variabel $\mathrm{X}$ terhadap $\mathrm{Y}$

b. Jika nilai sig $>0,05$, atau $t$ hitung $<\mathrm{t}$ tabel maka tidak terdapat pengaruh variabel $\mathrm{X}$ terhadap $\mathrm{Y}$

Tabel 4. Uji T

Coefficients $^{\mathrm{a}}$

\begin{tabular}{|c|c|c|c|c|c|c|}
\hline \multirow{2}{*}{\multicolumn{2}{|c|}{ Model }} & \multicolumn{2}{|c|}{$\begin{array}{l}\text { Unstandardized } \\
\text { Coefficients }\end{array}$} & \multirow{2}{*}{$\begin{array}{l}\text { Standardize } \\
\text { d } \\
\frac{\text { Coefficients }}{\text { Beta }}\end{array}$} & \multirow[b]{2}{*}{$\mathrm{t}$} & \multirow[b]{2}{*}{ Sig. } \\
\hline & & B & Std. Error & & & \\
\hline \multirow[t]{2}{*}{1} & (Constant) & 8,973 & ,913 & & 9,828 & ,000 \\
\hline & $\begin{array}{l}\text { Terpaan } \\
\text { Akun }\end{array}$ & ,211 & ,024 & 395 & 8,630 & ,000 \\
\hline
\end{tabular}

a. Dependent Variable: Preferensi

Berdasarkan hasil uji t diperoleh hasil bawa variabel X $8.630>1.965$ dan nilai Sig. 0.000 $<0.05$. angka tersebut menunjukan bahwa Ha diterima, Maka dapat disimpulkan bahwa terdapat pengaruh signifikansi antara terpaan akun terhadap preferensi dalam memilih kuliner di Bekasi. Dan hipotesis yang menyatakan bahwa "Pengaruh Terpaan Akun Instagram @bekasifood terhadap Preferensi dalam Memilih Kuliner di Bekasi" diterima. Atau $\mathrm{H}_{\mathrm{a}}$ diterima dan $\mathrm{H}_{0}$ ditolak.

\section{Uji Koefisien Determinasi}

Uji koefisien determinasi digunakan untuk mengukur seberapa jauh kemampuan model dalam menerangkan variasi variabel dependen. 
Tabel 5. Koefisien Determinasi

Model Summary

\begin{tabular}{|l|c|r|r|r|}
\hline Model & R & R Square & Adjusted R Square & Std. Error of the Estimate \\
\hline 1 & $.856^{\mathrm{a}}$ & .733 & .731 & 2.538 \\
\hline
\end{tabular}

a. Predictors: (Constant), Terpaan Akun

Untuk melihat besaran pengaruh terpaan akun (X) terhadap (Y) preferensi followers @ bekasifood, yaitu terlihat pada nilai R Square. Berdasarkan tabel diatas, dapat diketahui bahwa R Square menunjukan Koefisien Determinasi. Angka ini menunjukan presentase sumbangan pengaruh variabel independen terhadap variabel dependent. Nilai R Square yang didapat sebesar $73,3 \%$ artinya persentase sumbangan pengaruh variabel terpaan akun (X). Sedangkan sisanya 26,7\% dipengaruhi faktor lain yang tidak dibahas dalam penelitian ini.

\section{Hasil dan Pembahasan}

Sebagaimana yang disebutkan dalam teori Uses and Gratifications, orang secara aktif berusaha untuk memenuhi hirarki kebutuhannya. Kepuasan atau pemenuhan kebutuhan didefinisikan sebagai usaha mengungkapkan kebutuhan individu ditentukan oleh lingkungan sosial (social environment) (Effendy, 2017). Sedangkan motif memiliki banyak pengertian. Sebagai contoh, motif informasi, tentang bagaimana media akan membantu seseorang untuk mendapatkan informasi; motif identitas pribadi, cara untuk memperkuat nilai-nilai pribadi; motif integratif sosial, terjadi ketika mereka menggantikan media sebagai sahabat mereka; dan motif hiburan, yang menetapkan sebagai pelarian dari rutinitas atau masalah sehari-hari (Rakhmat, 2011).

Berdasarkan data hasil penyebaran angket kepada 400 responden followers akun Instagram @bekasifood yang berisikan 16 butir pertanyaan kuesioner, 11 butir pertanyaan tentang terpaan akun sedangkan 5 butir pertanyaan tentang preferensi. Berdasarkan variabel penelitian yang disusun, maka motif yang dimiliki followers akun Instagram @ bekasifood untuk melihat konten Instagram tersebut sangat beragam. Namun terdapat pengaruh yang signifikan yaitu motif hiburan, artinya responden mengharapkan pemenuhan kebutuhan akan hiburan khususnya dapat mengisi waktu luang dengan bermanfaat. Motif yang berpengaruh selanjutnya adalah motif informasi. Artinya responden mengharapkan informasi yang diperoleh itu terbaru dan sesuai fakta yang ada. Selain itu responden mengharapkan mendapatkan solusi terhadap masalah yang sedang dialami.

Motif yang berpengaruh ketiga adalah identitas diri. Motif ini berpengaruh karena responden ingin mendapatkan pembelajaran sikap dan juga ingin mendapat inspirasi dari narasumber yang dihadirkan. Selanjutnya mengenai motif yang tidak berpengaruh adalah motif integrasi dan interaksi sosial. Responden tidak membutuhkan bahan diskusi dengan orang lain dari akun Instagram @ bekasifood. Hal ini bisa diduga bahwa responden lebih tertarik membahas hal lain dibandingkan dengan membahas unggahan atau konten dari akun Instagram @ bekasifood.

Dengan demikian, motif yang dimiliki followers akun Instagram @ bekasifood beragam. Namun motif yang paling kuat terdapat pada motif hiburan dan motif informasi. Harapan sebagian besar responden untuk mendapatkan hiburan dan pengetahuan lebih dari sebuah 
tayangan memberikan pengaruh terhadap kebutuhan atau kepuasan akan informasi dan hiburan yang diharapkan terpenuhi dengan melihat postingan dari akun Instagram @bekasifood.

Motif yang dimiliki responden lebih banyak mengarah kepada hiburan dan pengetahuan. Hal ini terjadi karena yang menonton program ini berasal dari semua kalangan masyarakat yang mana keingintahuan akan informasi dan kebutuhan akan hiburan bisa mereka peroleh dari unggahan akun Instagram @ bekasifood. Dengan demikian, dapat dimaknai bahwa antara terpaan akun dan preferensi cukup berpengaruh khususnya pada followers akun Instagram @bekasifood.

\section{Penutup}

Terpaan akun Instagram @bekasifood dapat mempengaruhi preferensi dalam memilih kuliner di Bekasi. Hal ini dilihat dari perbandingan terpaan akun dan preferensi berdasarkan variabel penelitian bahwa pada penelitian ini motif yang dimiliki followers akun Instagram @ bekasifood beragam. Dapat dikatakan bahwa motif yang paling kuat terdapat pada motif hiburan, diikuti pada urutan kedua yaitu motif informasi, urutan ketiga motif identitas diri dan yang terakhir yaitu motif integrasi dan interaksi sosial yang berpengaruh terhadap preferensi dalam memilih kuliner di Bekasi. Hal ini diartikan bahwa responden mengharapkan pemenuhan kebutuhan akan hiburan khususnya dapat mengisi waktu luang yang bermanfaat dengan mengisi ruang keingintahuan akan fenomena edukatif yang ada di lingkungan sekitar.

Sementara itu, saran yang bisa diberikan adalah bahwa unggahan akun Instagram @ bekasifood cocok dilihat oleh masyarakat yang ingin mencari hiburan di saat waktu luang. Terlebih lagi unggahan akun Instagram @bekasifood mampu memenuhi kebutuhan penonton dalam kategori hiburan.

\section{Daftar Pustaka}

APJII. (2020). Survei pengguna internet APJII 2019-Q2 2020: Ada kenaikan 25,5 Juta Pengguna Internet Baru di RI. https://apjii.or.id/downfile/file/BULETINAPJIIEDISI74November2020.pdf

Ardianto, E. (2004). Komunikasi Massa Suatu Pengantar. Simbiosa Rekatama Media.

Baran, S. J., \& Davis, D. K. (2018). Teori Komunikasi Massa Edisi 5. Salemba Humanika.

Cahyono, A. S. (2016). Pengaruh media sosial terhadap perubahan sosial masyarakat di Indonesia. Jurnal Ilmu Sosial \& Ilmu Politik, 9(1), 140-157.

Effendy, O. U. (2017). Ilmu Komunikasi Teori dan Praktek. PT. Remaja Rosdakarya.

Herlambang, Y. (2014). Participatory Culture dalam Komunitas Online Sebagai Reperesentasi Kebutuhan Manusia. TEMATIK, 1(2), 26-34. https://doi.org/10.38204/tematik.v1i2.45

Hidayat, R. (2017). Peningkatan Aktivitas Komunikasi Interpersonal Dalam Organisasi Melalui Perbaikan Efikasi Diri, Kepemimpinan Dan Kekohesifan Tim. Kelola: Jurnal Manajemen Pendidikan, 4(2), 161-170. https://doi.org/10.24246/j.jk.2017.v4.i2.p161-170

Juwita, E. P., Budimansyah, D., \& Nurbayani, S. (2015). Peran Media Sosial Terhadap Gaya Hidup Siswa. SOSIETAS, 5(1). https://doi.org/10.17509/sosietas.v5i1.1513

Khumaedi, T., \& Diniyati, S. H. (2020). Komunikasi Islam dalam Perspektif Mahasiswa Islam. Al-Mubin; Islamic Scientific Journal, 3(2), 12-18. https://doi.org/10.51192/almubin.v3i2.74

Kriyantono, R. (2009). Teknik Praktis Riset Komunikasi. Prenada Media Group.

Kriyantono, R. (2016). Teknik Praktis Riset Komunikasi. Kencana Prenada Media Group.

Lestari, S. (2018). Peran Teknologi dalam Pendidikan di Era Globalisasi. EDURELIGIA; Jurnal Pendidikan Agama Islam, 2(2), 94-100. https://doi.org/10.33650/edureligia.v2i2.459

Lori, A. (2013). IKnowWhoYou AreandI SawWhatYouDid. Free Press.

Meilinda, N. (2018). Social Media on Campus: Studi Peran Media Sosial sebagai Media Penyebaran Informasi Akademik pada Mahasiswa di Program Studi Ilmu Komunikasi 
FISIP UNSRI. The Journal of Society \& Media, 2(1), 53-64. https://doi.org/10.26740/jsm.v2n1.p53-64

Mulawarman, M., \& Nurfitri, A. D. (2017). Perilaku Pengguna Media Sosial beserta Implikasinya Ditinjau dari Perspektif Psikologi Sosial Terapan. Buletin Psikologi, 25(1), 36-44. https://doi.org/10.22146/buletinpsikologi.22759

Nurudin. (2017). Pengantar Komunikasi Massa. PT Rajagrafindo Persada.

Perdana, K. E. (2021). Analisa Model Komunikasi Lasswell Pada Halaman “@aswaja_sunda” Dalam Turut Mempertahankan Ajaran Islam Ahlussunnah Wal Jamaah di Media Instagram. The International Journal of Pegon: Islam Nusantara Civilization, 5(01), 25-38. https://doi.org/10.51925/inc.v5i01.47

Purbohastuti, A. W. (2017). Efektivitas Media Sosial sebagai Media Promosi. Tirtayasa Ekonomika, 12(2), 212-231. https://doi.org/10.35448/jte.v12i2.4456

Rakhmat, J. (2011). Psikologi Komunikasi. Remaja Rosdakarya.

Ruslan, R. (2016). Manajemen Public Relations \& Media Komunikasi. PT Raja Grafindo Persada.

Sukrillah, A., Ratnamulyani, I. A., \& Kusumadinata, A. A. (2018). Pemanfaatan Media Sosial Melalui Whatsapp Group FEI Sebagai Sarana Komunikasi. Jurnal Komunikatio, 3(2), 95103. https://doi.org/10.30997/jk.v3i2.919

Tobing, S. M. (2019). Pemanfaatan Internet sebagai Media Informasi dalam Kegiatan Belajar Mengajar pada Mata Kuliah Pendidikan Pancasila. Jurnal Pekan: Jurnal Pendidikan Kewarganegaraan, 4(1), 64-73. https://doi.org/10.31932/jpk.v4i1.376

Widodo. (2017). Metodologi Penelitian Populer \& Praktis. Rajawali Pers. 